\title{
CFRP 繊維直角方向の引張強度の時間-温度依存性*
}

$$
\text { 宮野靖** 金光学***國尾武**** }
$$

\section{Time and Temperature Dependences of Transverse Tensile Strength of CFRP}

by

\author{
Yasushi MIYANO \\ (Kanazawa Institute of Technology, Kanazawa) \\ Manabu KANEMITSU \\ (Kanazawa Technical College, Kanazawa) \\ and Takeshi KUNIO \\ (Department of Mechanical Engineering, Keio University, Yokohama)
}

\begin{abstract}
To investigate the time and temperature dependences of the transverses tensile strength of unidirectional CFRP, tension tests were conducted at various temperatures and strain rates.

The transverse tensile strength of CFRP showed remarkable dependence upon time and temperature in the same manner as the tensile strength of the matrix. The master curve for the transverse tensile strength was able to be constructed by using their thermo-rheologically simple properties. The time and temperature shift factors for the fracture behaviors of both the matrix resin and the CFRP were quantitatively in good agreement, and also coincided well with those concerning the creep compliances of these materials. The observations by a scanning electron microscope showed that the appearance of fracture surface changed considerably with temperature.
\end{abstract}

キー・ワード : 複合材料, CFRP, 機械的性質, 引張強度

(Received Sep. 24, 1981)

\section{1 緒言}

宇宙開発用口ケットの構造部材を始めスポーツ用品 等に広く使用されている炭素繊維強化プラスチック (CFRP) を取上げ，その機械的性質の時間和よび温度 依存性について検討したものである.

CFRP の機械的性質には著しい異方性がある。つま り繊維方向の比強度, 比剛性は高いが繊維直角方向の 比強度, 比剛性は緘維方向に比べて著しく低いことが CFRP の一つの特徴である.CFRPを構造部材として 使用する場合は絨維方向はるちろんであるが緘維直角 方向の引張, 圧縮や繊維に沿ら方向のせん断が働くこ とになり，構造物の安全性を評価するう兄においても このような繊維直角方向の機械的性質を把握すること は重要な意義をるつことになる.

一方，マトリックスである樹脂の機械的性質には時 間依存性や温度依存性があり，つまり粘弾性挙動を示

* 原稿受理 昭和56年 9 月24日

** 正 会 員 金次工業大学 金次南局区内野々市町

*** 正会員 金次工業高等専門学校 金次南局区内野々市町

**** 正 会 員 慶応義熟大学理工学部 横兵市港北区日吉町
す.このことより CFRP の機械的性質においても時 間依存性や温度依存性を示すことが当然予想される. 著者らはすでに一方向強化 CFRP の絨維直角方向に ついてクリープュンプライアンス, 層間せん断強度, 曲げ強度の時間拉よび温度依存性を求めている. そし てこれらの諸性質には時間-温度換算則が 適用でき, このとき得られる時間-温度移動因子はマトリックス である樹脂の機械的性質の時間-温度移動因子とょく 一致することを明らかにしている。

本報告は既報で得た樹脂とこれをマトリックスとす る CFRP の機械的性質に括ける上述の相関関係が引 張強度に拈いても成立するか否かについて検討したも のである．すなわち，一方向強化 CFRP の緘維直角 方向について種々の一定温度と種々の定ひず反速度の 下で引張破断強度を求め, 応力ーひずみ関係等拈い て成立したと同様の 時間-温度換算則が引張破断強度 に成立するか否かについて考察し,さらに引張破断強

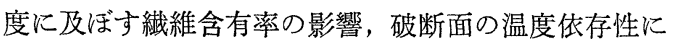
ついて考察を加えたものである.

\section{2 実 験 方 法}


Table I. Compositions and cure cycle of resin and CFRP.

\begin{tabular}{l|c}
\hline \multicolumn{2}{c}{ Composition } \\
\hline \multicolumn{1}{c|}{ Resin } & CFRP \\
\hline $\begin{array}{c}\text { Epoxy: EPIKOTE 828/100* } \\
\text { Hardener: methy1 himic } \\
\text { anhydride/104* } \\
\text { Cure accelerator: 2-ethyl-4- } \\
\text { methylimidazol/1* }\end{array}$ & $\begin{array}{l}\text { Matrix: Epoxy resin } \\
\text { Carbon fiber: TORAYCA } \\
\text { T300 3 000 fil. } \\
\text { Volume fraction of fibers. } \\
589 \%\end{array}$ \\
\hline
\end{tabular}

Cure cycle

$12 \mathrm{~h}$ at $70^{\circ} \mathrm{C}$ and $5 \mathrm{MPa}, 4 \mathrm{~h}$ at $150^{\circ} \mathrm{C}$ and $2 \mathrm{~h}$ at $190^{\circ} \mathrm{C}$

* 100, 104 and 1 show the weight ratio.

\section{$2 \cdot 1$ CFRP 板の製作}

用いた一方向強化 CFRP の成分ならびに硬化条件 を Table I 飞示寸。一方向強化 CFRP の成形方法は 試作した繊維巻き取り機により巻き取り板に炭素瀻維 を張力 $10 \mathrm{~N}$ ，ピッチ $0.5 \mathrm{~mm} て ゙ 8$ 層巻き取り，樹脂を 真空含浸し，これを金型内に入れ，試作した加圧恒温 槽により $70^{\circ} \mathrm{C}, 5 \mathrm{MPa}$ で12時間の硬化の後, 常圧で Table I に示す条件に上り後硬化を行い, $150 \mathrm{~mm} \times$ $150 \mathrm{~mm}$ で厚さ $3 \mathrm{~mm}$ の CFRP 板を成形した. CFRP のボイドについては顕微鏡（倍率 800）によりこれが ないことを確認した．炭素瀻維体積含有率 $V_{f}$ は比重 法により求め, $V_{f}=58.9 \%$ を得た。

\section{$2 \cdot 2$ 樹脂および CFRP の機械的性質}

マトリックスである樹脂と製作した一方向強化 CFRP の機械的性質を Table II に示す. 縦弾性係数, 引張強度, 曲げ強度は室温23での值であり, ガラス 転移点 $T_{g}$ は Fig. 1 亿示す加熱による線膨張の関係よ り求めた。

Fig. 2 亿基準温度 $T_{0}=100 \mathrm{C}$ と括いて換算時間 $t^{\prime}$ に対する樹脂と CFRP 繊維直角方向のクリープュン プライアンスのマスター曲線 $D_{m}\left(t^{\prime}, T_{0}\right), D_{c}\left(t^{\prime}, T_{0}^{1)}\right)$

Table II. Mechanical properties of resin and unidirectional CFRP.

\begin{tabular}{|c|c|c|c|c|}
\hline \multirow{2}{*}{\multicolumn{2}{|c|}{ Item }} & \multirow{2}{*}{ Resin } & \multicolumn{2}{|c|}{ CFRP } \\
\hline & & & L* & $T^{*}$ \\
\hline Density & $\mathrm{kg} / \mathrm{m}^{3}$ & 1. $22 \times 10^{3}$ & \multicolumn{2}{|c|}{ 1. $53 \times 10^{3}$} \\
\hline Young's modulus & $\mathrm{GPa}$ & 3.3 & 120 & 8.8 \\
\hline Tensile strength & $\mathrm{MPa}$ & 76 & 1640 & 65 \\
\hline Flexural strength & $\mathrm{MPa}$ & 153 & 1350 & 67 \\
\hline \multirow{2}{*}{$\begin{array}{l}\text { Coefficient } \\
\text { of thermal } \\
\text { expansion }{ }^{\circ} \mathrm{C}^{-1}\end{array}$} & $<125^{\circ} \mathrm{C}$ & $69 \times 10^{-6}$ & $0 \times 10^{-6}$ & $44 \times 10^{-6}$ \\
\hline & $>125^{\circ} \mathrm{C}$ & $140 \times 10^{-6}$ & $0 \times 10^{-6}$ & $111 \times 10^{-6}$ \\
\hline \multicolumn{2}{|c|}{$\begin{array}{l}\text { Glass transition } \\
\text { temperature }{ }^{\circ} \mathrm{C}\end{array}$} & 125 & - & 125 \\
\hline
\end{tabular}

* $\mathrm{L}$ and $\mathrm{T}$ represent the longitudinal and the transversal direction.

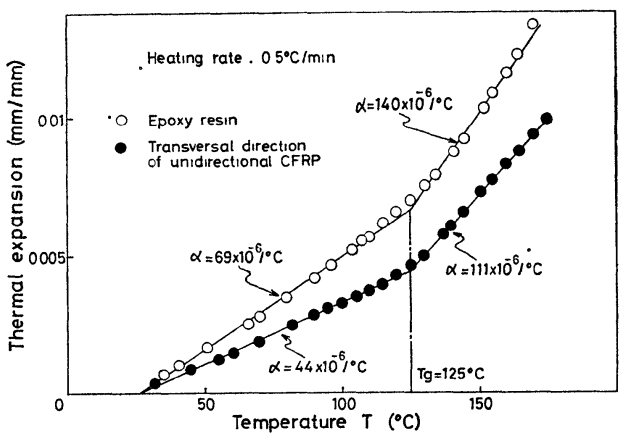

Fig. 1. Thermal expansion of epoxy resin and transversal direction of unidirectional CFRP.

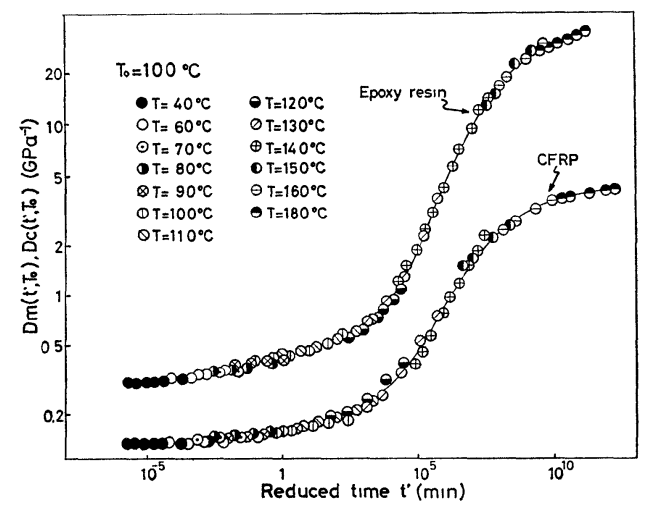

Fig. 2. Master curves for creep compliance of epoxy resin and transversal direction of unidirectional CFRP.

を示す。

\section{$2 \cdot 3$ 試験条件}

上述の CFRP 板より試験片の長手方向に対して繊 維の方向が直角になるように引張試験片を切り出した。 試験片寸法および試験方法は JIS K7113 に準じ, 定 ひずみ速度の引張試験は恒温槽付精密万能試験機（島 津製作所製，オートグラフ DSS-10T) を用いて行っ た. 温度条件は $T=60,80,100,120,140,160$ ， $180^{\circ} \mathrm{C}$ の 7 段階，クロスヘッド間の定変位速度条件は $V=0.05,0.5,5,50 \mathrm{~mm} / \mathrm{min}$ の 4 段階で行った. 同一条件での試験片数は各 5 個とした. 定変位速度 $V$ と定ひずみ速度 $R$ の関係は次式となり，

$$
R=k \cdot V
$$

係数 $k$ は常温にお斿るクロスヘッド間の変位と試験片 中央のひずみの関係より求めた。

試験片破断時の荷重 $W_{b}(R, T)$ おょよ゙クロスへッ ド間の変位 $U_{b}(R, T)$ を測定し, 次式より破断強度 $F_{c}(R, T)$ および破断ひずみ $S_{c}(R, T)$ を求めた。

$$
F_{c}(R, T)=\frac{W_{b}(R, T)}{b \cdot h}
$$

ここで, $b:$ 試験片の幅, $h:$ 試験片の厚さ 


$$
S_{c}(R, T)=k \cdot U_{b}(R, T)
$$

\section{3 結果および考察}

$3 \cdot 1$ CFRP 繊維直角方向の引張破断強度 $\boldsymbol{F}_{c}(\boldsymbol{R}$, $T)$ および破断ひずみ $S_{c}(R, T)$ の時間お よび温度依存性

各測定温度Tに拈ける CFRP 繊維直角方向の引張 破断強度 $F_{c}(R, T)$ と定ひずみ速度 $R$ との関係を Fig 3 に○印で示す. この図より $F_{c}(R, T)$ は温度の上 昇とともに小さくなり，定ひずみ速度Rが高くなるほ ど大きくなることがわかる。つぎに同図において○印 で示すマトリックスであるエポキシ樹脂の引張破断強 度 $F_{m}(R, \stackrel{2}{T})$ と対比する. $F_{m}(R, T)$ の大きいガラ ス状領域では $F_{c}(R, T)$ b大きく, $F_{m}(R, T)$ が低 下する粘弾性領域では $F_{c}(R, T)$ も同様に低下する. すなわち CFRP の引張破断強度 $F_{c}(R, T)$ とマトリ ックスである樹脂の引張破断強度 $F_{m}(R, T)$ の時間 および温度依存性が同じ傾向を示すことが認められる.

つぎに，各測定温度 $T$ に和ける CFRP 繊維直角方 向の引張破断ひずみ $S_{c}(R, T)$ と定ひずみ速度 $R$ との
関係を Fig.4 に○印で示す。この図より破断ひずみ $S_{c}(R, T)$ も温度や定ひずみ速度 $R$ により変化するこ とがわかる，同図に抋いて○印で示すマトリックスで あるエポキシ樹脂の引張破断ひずみ $S_{m}(R, T)$ ） と対 比する. $S_{m}(R, T)$ の小さい領域では $S_{c}(R, T)$ も 小さく, $S_{m}(R, T)$ が大きくなる領域では $S_{c}(R, T)$ も同様に大きくなる．すなわち CFRP の引張破断強 度と同様に CFRP の破断ひずみ $S_{c}(R, T)$ もマトリ ックスである樹脂の破断ひずみ $S_{m}(R, T)$ の時間お よび温度依存性と同じ傾向を示すことがわかる。すな わち CFRP の繊維直角方向の引張破断の時間拉よび 温度依存性はマトリックスである樹脂の引張破断の時 間および温度依存性と非常によく対応する.

$3 \cdot 2$ CFRP 繊維直角方向の引張破断強度 および 破断ひずみのマスター曲線 $\boldsymbol{F}_{c}\left(\boldsymbol{R}^{\prime}, \boldsymbol{T}_{0}\right)$, $\boldsymbol{S}_{c}\left(\boldsymbol{R}^{\prime}, \boldsymbol{T}_{0}\right)$

Fig. 3 の各測定温度, 各定ひずみ速度の $F_{c}(R, T)$ の平均值について対数定ひずみ速度軸に沿って平行移 動し，なめらかに接続するようにしたところ Fig. 5

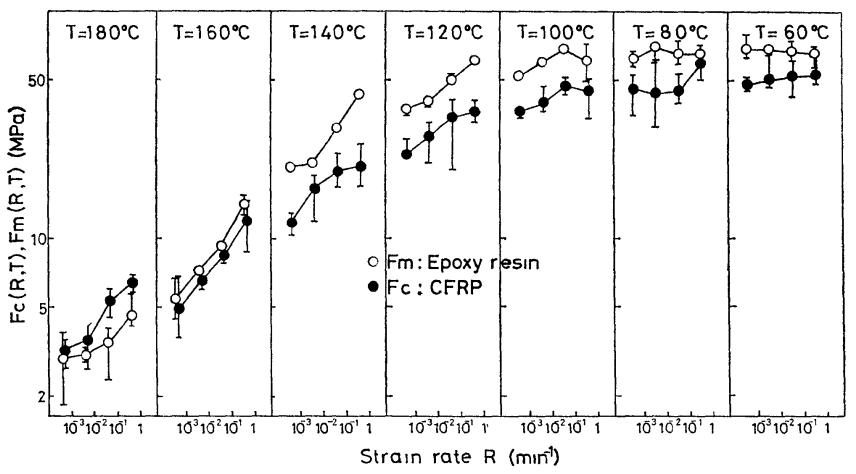

Fig. 3. Transverse tensile strength of unidirectional CFRP and tensile strength of epoxy resin against strain rate.

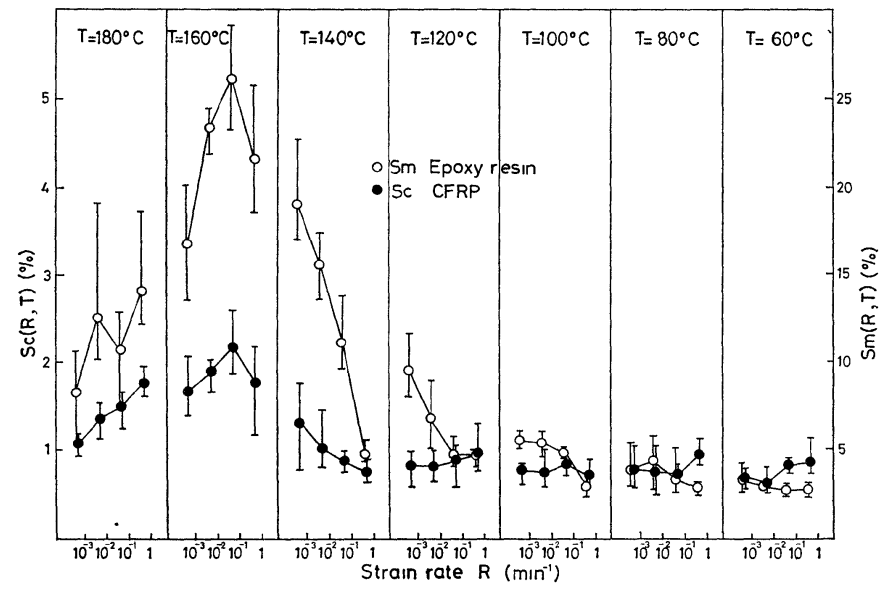

Fig. 4. Transverse ultimate strain of unidirectional CFRP and ultimate strain of epoxy resin against strain rate. 


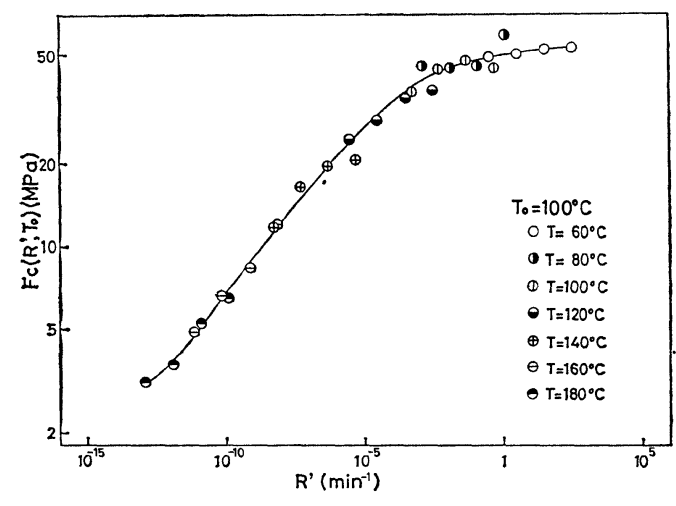

Fig. 5. Master curve for transverse tensile strength of unidirectional CFRP.

に示すよらな 1 本の曲線が得られ, 基準温度 $T_{0}=100$ ○に扣いて 換算定ひずみ速度 $R^{\prime}$ に対する CFRP 緎 維直角方向の引張破断強度のマスタ一曲線 $F_{c}\left(R^{\prime}, T_{0}\right)$ が求まった。これより CFRP の繊維直角方向の引張 破断強度には時間-温度換算則が成立し，非常に低い 定ひずみ速度より高い定ひずみ速度の引張破断強度の 予測が可能となった。

つぎに, Fig. 4 に示す各測定温度，各定ひずみ速度 の $S_{c}(R, T)$ の平均值に時間-温度換算則を適用した ところ Fig. 6 に示すよらな 1 本の曲線が得られた. すなわち基準温度 $T_{0}=100{ }^{\circ} \mathrm{C}$ において 換算定ひずみ 速度 $R^{\prime}$ に対する CFRP 繊維直角方向の引張破断ひ ずみのマスター曲線 $S_{c}\left(R^{\prime}, T_{0}\right)$ が求まった。

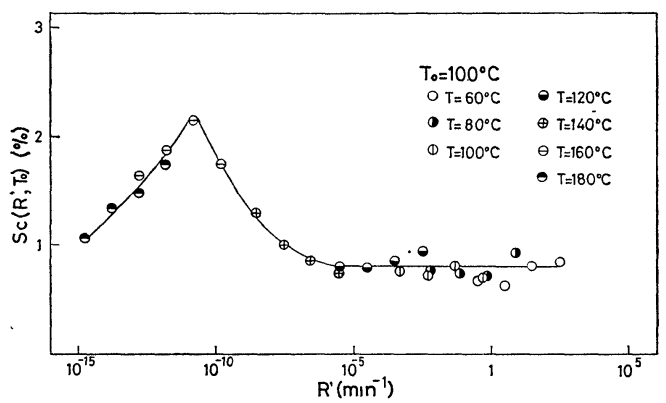

Fig. 6. Master curve for transverse ultimate strain of unidirectional CFRP.

つぎに,これらのマスター曲線作成の際の対数定ひ ずみ速度軸に沿っての平行移動量つまり時間-温度移 動因子 $a_{T_{0}}(T)$ を温度に対してプロットしたものを Fig. 7 に示す。 この図より明らかなように CFRP の $F_{c}(R, T), S_{c}(R, T)$ の $a_{T_{0}}(T)$, マトリックスであ る樹脂の $F_{m}(R, T), S_{m}(R, T)$ の $a_{T_{0}}(T)$ および 既報で得られた CFRP および樹脂の応力ーひずみ関係 すなわちクリープュンプライアンスの $a_{T_{0}}(T)$ がほぼ 一致している. これより CFRP とマトリックスであ

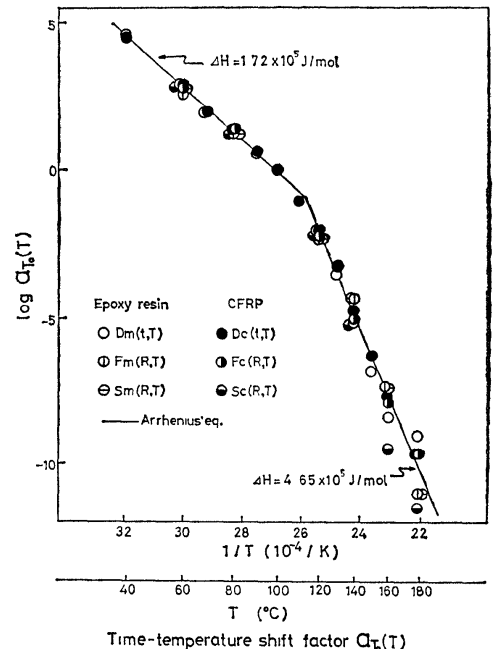

Fig. 7. Time-temperature shift factors $a_{\mathrm{To}}(T)$.

る樹脂には応力ーひずみ関係から引張破断にいたるま で同一の時間-温度換算則が適用できることがわかっ た. そして低温領域および高温領域に括いて活性化エ ネルギ $\Delta H=1.72 \times 10^{5} \mathrm{~J} / \mathrm{mol}, 4.65 \times 10^{5} \mathrm{~J} / \mathrm{mol}$ とした 2 本のアレニュース式で表現できることがわかった.

そして 2 本のアレニュース式の接続点に括ける温度 はガラ不転移点近傍である $114^{\circ} \mathrm{C}$ を示し', この温度 を境にして変形や破壊の様式が異ることが推測され る.

\section{$3 \cdot 3$ CFRP の引張破断と樹脂の引張破断の 相関 関係}

Fig. 8 に種々の温度, 定ひずみ速度に和ける CFRP の破断ひずみ $S_{c}(R, T)$ と引張破断強度 $F_{c}(R, T)$ の関係を○印で示し，マトリックスである樹脂の破断 ひずみ $S_{m}(R, T)$ と引張破断強度 $F_{m}(R, T)$ の関係 を○印で示す。同図よりマトリックスである樹脂の

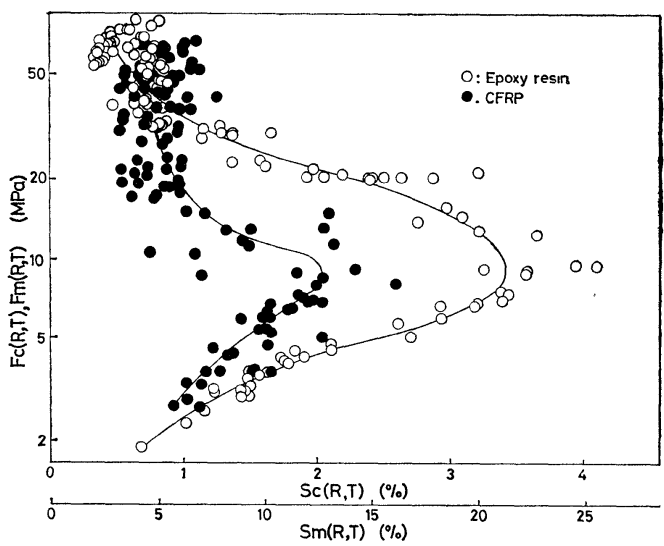

Fig. 8. Relation between tensile strength and ultimate strain of CFRP and epoxy resin at various conditions. 
$F_{m}(R, T)$ が大きく $S_{m}(R, T)$ の小さい領域では CFRP，も同様に $F_{c}(R, T)$ が大きく $S_{c}(R, T)$ が小 さく, $F_{m}(R, T)$ が小さくなり $S_{m}(R, T)$ が大きい 領域は $\mathrm{CFRP}$ の $F_{c}(R, T)$ む小さくなり $S_{c}(R, T)$ は大きくなっている. そして $F_{m}(R, T)$ ๖ $S_{m}(R, T)$ も小さくなる領域では CFRP も同様の傾向を示すこ とが認められる.すなわち CFRP の繊維直角方向の 引張破断の包絡線はマトリックスである樹脂の引張破 断の包絡線と非常によく対応することが認められた.

つぎに同一の温度条件，定ひずみ速度条件での CFRP 引引張破断強度 $F_{c}(R, T)$ とマトリックスで ある樹脂の引張破断強度 $F_{m}(R, T)$ の関係を Fig.9 に示す. この図より $F_{c}(R, T)$ と $F_{m}(R, T)$ は 1 本 の曲線で表現できる.すなわち両者の関係は温度やひ ずみ速度のような環境には関係なく一義的に決まると いえる. Fig.10 は同一の温度条件, 定ひずみ速度条 件での CFRP の引張破断ひずみ $S_{c}(R, T)$ とマトリ ックスである樹脂の引張破断ひずみ $S_{m}(R, T)$ の関 係を示したものである.この図より両者の関係は引張 破断強度之同様に温度やひずみ速度のような環境には 関係なく一義的に決まることがわかる。

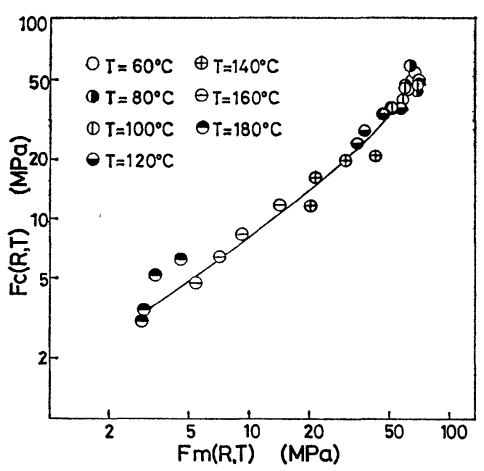

Fig. 9. Relation between transverse tensile strength of unidirectional CFRP and tensile strength of epoxy resin.

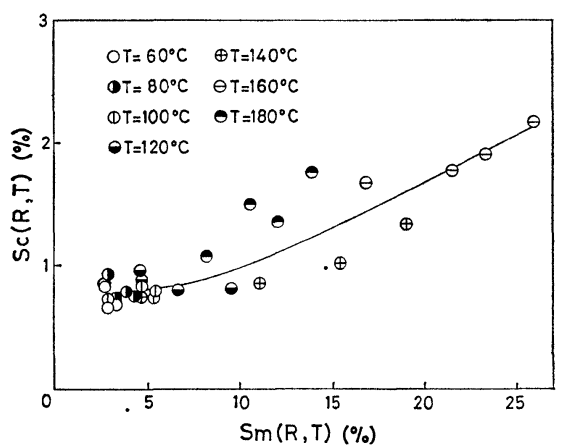

Fig. 10. Relation between transverse ultimate strain of unidirectional CFRP and ultimate strain of epoxy resin.

\section{$3 \cdot 4$ CFRP 繊維直角方向の引張破断強度 $\boldsymbol{F}_{c}(\boldsymbol{R}$, T) に及ぼす繊維含有率の影響}

CFRP 板製作時に巻き取り板に炭素繊維を 8 層巻き 取った $V_{f}=58.9 \%$ のものに加光, さらに 6 層および 10層で巻き取った $V_{f}=44.3 \%, 68.1 \%$ ののを製作 した.これら 3 種類の繊維含有率の CFRP 板につい て $F_{c}(R, T)$ を定変位速度 $V=5 \mathrm{~mm} / \mathrm{min}$ の条件で 種々の盜度条件の下で求めた. Fig. 11 は $V_{f}$ に対す る CFRP の $F_{c}(R, T)$ を種々の温度条件に対して示 したものである.この図より，マトリックスである樹 脂の $F_{m}(R, T)$ の大きい低温領域では $V_{f}$ が増加し ても CFRP の $F_{c}(R, T)$ はほとんど変化しないが, 温度が上り $F_{m}(R, T)$ が下るに従い $V_{f}$ が増加する ほど CFRP の $F_{c}(R, T)$ が大きくなることが認めら れる。

つぎに種々の測定温度に括ける繊維含有率 $V_{f}$ と CFRP の引張破断ひずみ $S_{c}(R, T)$ の関係を Fig. 12 に示す. 同図より, 種々の測定温度に和いて $V_{f}$ が增 加するほどわずかに破断ひずみが小さくなることが認 められる。

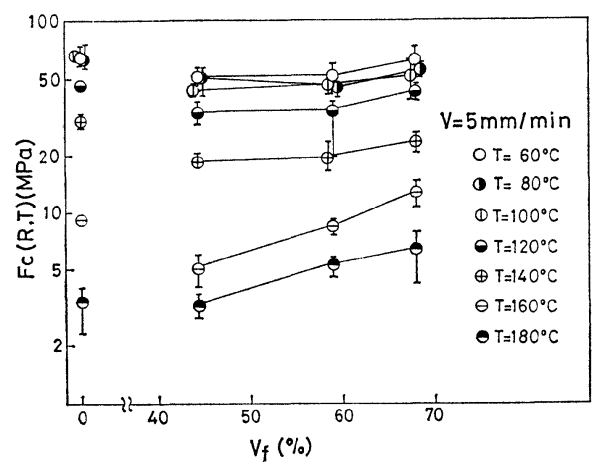

Fig. 11. Transverse tensile strength versus volume content of carbon fibers.

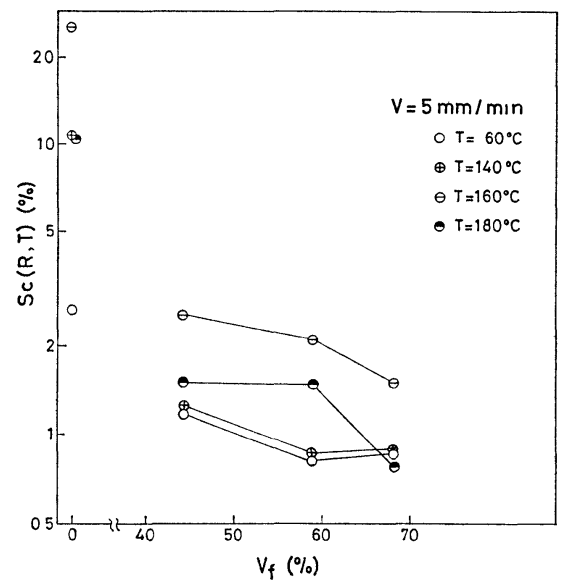

Fig. 12. Transverse ultimate strain versus volume content of carbon fibers. 

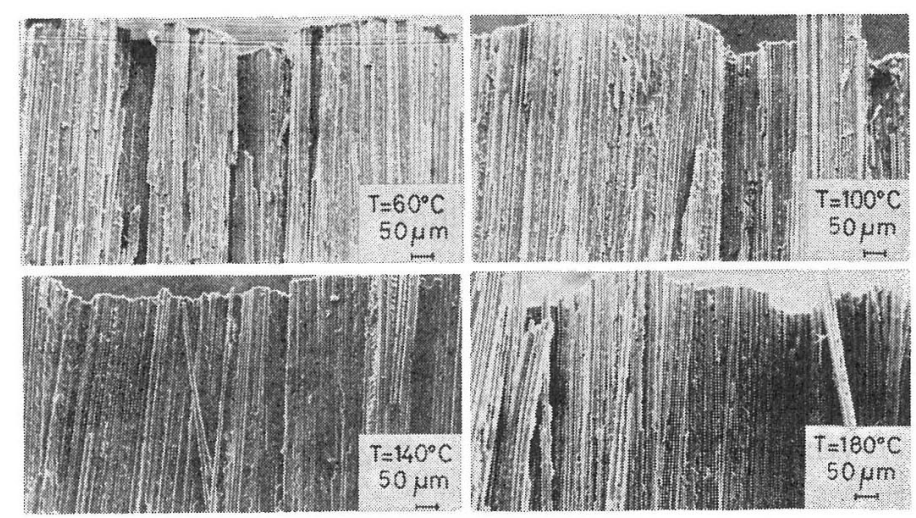

Fig. 13. Fractographs of transverse tensile fracture of unidirectional CFRP.

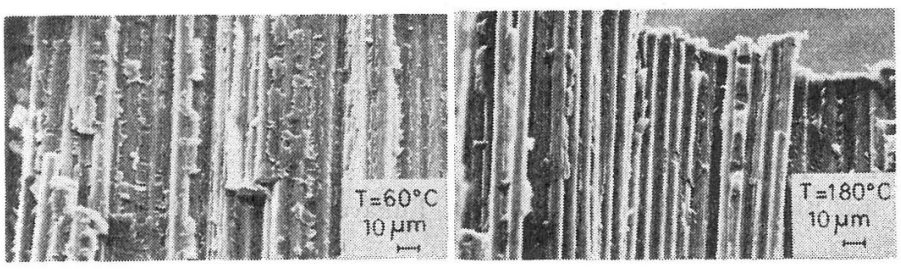

Fig. 14. Fractographs of transverse tensile fracture of unidirectional CFRP.

時間および温度依存性がある。

(2) CFRPは熱レオロジー的に単純 な材料であり，時間-温度換算則が適 用できる。これより CFRP の引張破 断強度と破断ひずみのマスター曲線が 求季った。

（3） CFRP の引張破断強度と破断ひ ずみには応力ーひずみ関係に执いて成 立したものと同一の時間-温度換算則 が適用でき, から樹脂単体の応力ーひ ずみ関係より破壞にいたるまでの時間 一温度換算則とも一致することが明ら かになった。 そしてこれらの時間-温 度移動因子は活性化エネルギの異る 2 本のアレニュース式で近似できる.

(4) CFRP の引張破断強度とマトリ ックスである樹脂の引張破断強度の関 係は温度やひずみ速度のよらな環境に は関係なく繊維含有率の上らな要因に より一義的に決まる。

\section{3・5 CFRP 破断面の SEM 観察}

づ゙繊維含有率 $V_{f}=58.9 \%$ の CFRP 繊維直角 方向の引張破断面を走查型電子顕微鏡（日立製作所製 HSM-2B) により観察した。CFRP 破断面には真空中 で金蒸着を厚さ 300 400 圶目途に施した。定変位 速度 $V=5 \mathrm{~mm} / \mathrm{min}$ で種々の温度に拈ける破断面の SEM 写真を Fig. 13 に示す。この図より低温で樹脂 のガラス状領域においては, 破断面の凹凸がはげしく, 纎維の破断がみられる。温度が上昇し， $T=140^{\circ} \mathrm{C} の$ 粘弾性領域になると破断面の凹凸は少くなり繊維の破

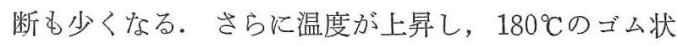
領域では再び破断面の凹凸がはげしくなるが，ここで は繊維の破断はほとえど見られず, 繊維のはく離現象 が認められる。Fig. 14 に $T=60^{\circ} \mathrm{C} ， 180^{\circ} \mathrm{C}$ の桩大 SEM 写真を示す。この図より低温と高温では繊維に対する 樹脂の付着の様相がかなり異る.すなわち低温では樹 脂は繊維にびっしりと付着しているが，高温ではこの 付着はみられず繊維は露出している。すなわち低温に お忷る樹脂の凝集破壞が温度の上昇とともに界面破壞 に移ることが認めら机る。

\section{4 結論}

エポキシ樹脂をマトリックスとした一方向強化 CFRP の䋐維直角方向の引張破断強度を種々の温度条 件, 種々の定でずみ速度条件の下で求めた結果, 次の ことがわかった。

（1） CFRP の引張破断強度と破断ひずみには著しい
（5）繊維含有率44.3\%，58.9\%，68.1\%の3 種類の CFRP の引張破断強度の温度依存性について比較した ところ，マトリックスである樹脂の引張破断強度の大 きい低温領域では同一温度条件での破断強度の差はほ とんど見られないが，温度が上り樹脂の破断強度が下 るに従い䋐維含有率が大さくなると CFRP の破断強 度は大きくなることが涊められた。

(6) CFRP の破断面を SEM 観察したところ, 破断 面の様相に温度依存性が認められた。

終りに本研究に対して多大のご助力を賜わった青山 学院大学理工学部・隆雅久教授, 日立製作所生産技術 研究所・磯貝時男博士, ならびに金沢工業大学・中川 多津夫教授, 杉森勝氏, 新保實氏に対し心から感謝し ます。

（昭和55年 9 月18日 第24回材料研劣連合講演会にて講演）

\section{参考文 献}

1) 宮野 清, 金光 学, 國尾 武, 材料, 28, 1098(1979)。 2）宮野 靖, 金光 学, 國尾 武, 材料, 29, 1208(1980).

3) Miyano, Y., M. Kanemitsu, and T. Kunio, IV National and I International Meeting on Composite Materials in Milano (1980).

4) 鈴木克人, 宮野 靖, 國尾 武, 高分子論文集, 33, 271 (1976).

5）たとえば，佐藤良泰，高分子， 15，665（1966). 